\title{
Half-Life TAU
}

National Cancer Institute

\section{Source}

National Cancer Institute. Half-Life TAU. NCI Thesaurus. Code C147483.

Half-life calculated within a dosing interval. 